\title{
Why Does Marxism Work from the Centenary of the Founding of the Party
}

\author{
Ying Ding $1{ }^{1 *}$ Ningfang Yang ${ }^{2}$ \\ ${ }^{1}$ School of Marxism China Jiliang University, Hangzhou 310018, China \\ ${ }^{2}$ School of Marxism China Jiliang University, Hangzhou 310018, China \\ * Corresponding author. Email: 1419436980@qq.com
}

\begin{abstract}
In the centenary of the founding of the Party, from the perspective of the Communist Party of China, thinking about why Marxism "works" is conducive to understanding that the Communist Party of China is a believer, implementer and innovator of Marxism. Under the leadership and dissemination of the Communist Party of China, Marxism still glows with intense vitality in contemporary China and even in the world. By specifying the relationship between the Communist Party of China and Marxism, we can better uphold the leadership of the Party, strengthen our ideals and beliefs, and build a strong China. Marxism, with its integrity, is a viewpoint and method containing the light of truth, which can give a reasonable explanation to everything in the world and guide our life path. After a hundred years of struggle, the Communist Party of China has condensed all the Chinese sons and daughters into a force, and under the bright light of Marxism, it has supported China, the oriental dragon, to take off constantly.
\end{abstract}

Keywords: Centennial Party Building, Marxism, the Communist Party of China.

\section{INTRODUCTION}

Walk, people's steps tend to be the same. The original meaning of "Walk" is the meaning of road. From this point of view, why Marxism works can also be understood as what chooses the road of Marxism. This involves who chooses, when, how and what is the result of the choice. "Why Marxism works" is first of all a theoretical problem from the real life of the masses. On the one hand, it arouses people's interest and promotes the development of research; On the other hand, the obscure theoretical content is expressed in the form loved by the people, so as to explain it in simple terms. For example, from the perspective of the excellent quality and function of Marxist theory itself, Marxism is a scientific, people's, practical, continuously developing and open theoretical system [1]. From the comparison between Marxism and other theories, compared with their obvious defects and problems, it has incomparable advantages of authenticity, integrity, system and comprehensiveness. Marx put forward "changing the world" in the last finale of the outline on Feuerbach. The importance of human initiative and practice is self-evident here. This is not only the historical mission of Marxist philosophy, but also the actual responsibility of every Marxist. Based on reality, the Communist Party of China has been born for nearly 100 years, which is the most vivid and powerful answer to why Marxism works.

\section{THE COMMUNIST PARTY OF CHINA CHOSE MARXISM}

The reason why Marxism "works" is that the Communist Party of China has chosen Marxism, which has believers like the Chinese Communists. Any theory, even the theory derived from practice and containing the light of truth, cannot function independently as an object itself. If it wants to realize its own value, it must establish the relationship between subject and object through people's subjective initiative and people's objective activities, so that people can have theoretical guidance and theory can be put into action [2]. For Marxist theory, the Communist Party of China is the "person" it needs. Since the birth of the Communist Party of China on the boat of Nanhu, the seeds of Marxism have already coexisted in the hearts of more than a dozen representatives and more than 50 party members. From the rise of Marxism in China to its selection by the Communist Party of China, it is the result of historical joint force. The Communist Party of China was born in confused China. Countless people with lofty ideals are committed to finding a new way out 
for China. The failure to explore the capitalist road has not extinguished the fighting spirit of the Chinese people. The ideological trend of utopian socialism has a tacit understanding with the ideal of Datong society in ancient China, The crisis of Western capitalist culture and the surging of socialist thoughts finally made the balance of the times tend to socialism. The October Revolution made China at the crossroads choose Marxism among the dense socialist thoughts. This choice is the result of the joint action of rational thinking and practical needs. It is the newly established Communist Party of China that made this choice. Because of this, at the beginning of its founding, the Communist Party of China was a party based on Marxist theory. Marxism gave the Communist Party of China theoretical guidance, and the Communist Party of China let Marxism take root and germinate in its own soil. For this newborn party, the lack of theory can be made up through learning, and the lack of experience can be accumulated through practice. As long as we adhere to the correct direction, the party's weakness can be overcome, and this basic direction is Marxism. After the introduction of Marxist theory into China, the Communist Party of China came into being in the development of the surging international and domestic revolutionary situation at that time. On the one hand, it contributed to the further spread of Marxism in China, on the other hand, it led the Chinese people to victory in the practical struggle. Therefore, the Young Communist Party of China grew up tenaciously in the face of difficulties and difficult environment. With the combination of theory and practice, no matter what setbacks it encountered, even if it occasionally deviated from its course, the Communist Party of China unswervingly grasped the direction of Marxism. The Communist Party of China chose and adhered to Marxism, which is inseparable from the role of the leaders of the early Communist Party of China. The choice is ultimately made by people and can play a role through talents, but this does not mean that our choice is accidental. The choice of Marxism is indeed the necessity of social and historical development, which is indisputable.

The theoretical attribute of Marxism is grasped by the Communist Party of China. Our party understands and gives full play to the scientific, people's, practical and open theoretical advantages of Marxism. It has always attached importance to theoretical learning and has carried out various learning activities for many times, including literacy education and ideological and political work for the broad masses of workers and peasants deeply understand the taste of truth; The guiding position of Marxism is upheld by the Communist Party of China. The party has always taken Marxism as the guiding ideology. In different historical periods of revolution, construction and reform, no matter how difficult the social situation is and how eroded other ideological trends are, the Communist Party of China has not shaken the guiding position of Marxism and its own faith is indestructible; The realistic core of Marxism is applied by the Communist Party of China. Our party always adheres to practice to produce true knowledge, attaches importance to initiative, transformation and action, and makes the theories of "specific analysis of specific problems" and "seeking truth from facts" blossom with Chinese characteristics in China. Marxism is not "acclimatized" in China because the Chinese Communists are good at combining their principles and theories with China's local reality, forming a series of ideological fruits of the Sinicization of Marxism with their own characteristics. Instead of following behind the Soviet Union, we "surrounded the city by the countryside". This is to make use of the characteristics of the situation of Chinese farmers and proceed from the local reality, and finally achieve great success. The Communist Party of China has always been so in its hundred years of struggle, its original intention has not changed, and has been making in-depth exploration on how to understand Marxism more deeply and how to give full play to the role of Marxism more effectively. The Communist Party of China chose Marxism instead of anything else. Marxism is the belief of the Chinese Communists. The word "belief" first appeared in Buddhist classics and was also called worship. In the original sense, it mainly refers to the belief in heaven, earth and ancestors. It can be seen that faith was originally derived from worship, which is not impossible for Marxism. Communists undoubtedly worship Marxism. With the development of the times, the meaning of the word "belief" is gradually generalized and can be used in customs, politics and other fields. Marxism is both ideological and political to us; It is both science and faith. Not every theory has conditions and abilities, with the color of politics and science, but Marxism has this magic, which is inseparable from the efforts of the Communist Party of China. Everyone should be responsible for his choice, and so should the Communist Party of China. Since he has chosen Marxism, he should unswervingly stick to it and stick to it. In the torrent of history, the Communist Party of China has chosen Marxism and believed in Marxism. For a hundred years, it has withstood the test of the masses and the times, found the right direction, and created a foundation for China's future development. This is a vivid interpretation of why Marxism "works".

\section{THE COMMUNIST PARTY OF CHINA HAS IMPLEMENTED MARXISM}

The reason why Marxism "works" is that the Communist Party of China has implemented and disseminated Marxism in the historical process of China's revolution, construction and reform. Marxism has been proved by the historical development of 
China's modern society. After the founding of the Communist Party of China, based on its national conditions, it held meetings to repeatedly discuss and formulate the revolutionary program. Seeing the strength of the workers and peasants and uniting with them, the Chinese revolution soon appeared a new situation, which is also closely related to the people's nature of Marxism. The Chinese Communists made good use of this point and laid the groundwork for a broad united front in the future; In the process of the great revolution, the Communist Party of China concentrated on strengthening its ties with workers, played a decisive role in promoting the cooperation between the Kuomintang and the Communist Party, and accelerated the pace of the Chinese revolution. Although there are various reasons for the ultimate failure of this revolution, including the bourgeois rebellion and the right opportunistic mistakes of our party, this can not erase the experience and lessons learned by the Communist Party of China in this experience [3]. One of the most important contents of Marxism is dialectics. We should look at problems from the perspective of movement, change and development, distinguish enemies and friends at any time, and correct mistakes in time. We should not use invariable and rigid things to guide specific actions, but should give full play to people's initiative as the main body and turn negative aspects into positive aspects; After the failure of the great revolution, the Communist Party of China independently led its people in a series of anti imperialist and anti feudal struggles, created its own army and rural base areas, accumulated certain strength, and created rich conditions for "qualitative change". After that, under the new historical conditions of the Anti Japanese War, the Communist Party of China once again implemented the basic principles of Marxism and played a creative role in the united front and armed struggle. These are examples of the CPC's implementation of Marxist thought. After the victory of the war of resistance against Japan for 14 years, the Communist Party of China was wholeheartedly committed to China's peace and liberation. In the confrontation with the Kuomintang, it finally won the victory of the new democratic revolution and opened a new chapter in the construction of new China. It can be said that the victory of China's revolution was achieved under the guidance of Marxism. Moreover, in the process of guiding Marxist theory, because it combined with China's national conditions and produced new theories, it formed the great Mao Zedong Thought and found the magic weapon to win the victory of the Chinese revolution. The echo of history and the spark of theory profoundly answered why Marxism "works".

After the founding of new China, how to consolidate the leadership of the Communist Party of China and how to protect the nascent state and political power were "eyeing" by all forces. In fact, the Communist
Party of China has never let people down. Under the leadership of the Communist Party of China, the people of all ethnic groups in China have opened up new roads and moved towards a new life, completed socialist industrialization and the transformation of the three major industries, and entered the primary stage of socialism. Of course, there will be mud and obstacles in this process, but how can the Chinese people lose and how can the Communist Party of China give up. Although socialist construction has made twists and turns in exploration, this is an attempt by the Communist Party of China to lead the Chinese people in socialist construction. We have no condition to "look forward on the shoulders of giants". We can only explore the laws and mysteries of socialist construction in constant exploration, and it is precisely because of the guidance of Marxism that we can still move towards the right road even if we have experienced a small fork in the road. Since the reform and opening up, China's economy has developed rapidly, and the picture of the new situation of modernization has been slowly unfolded. Deng Xiaoping, Jiang Zemin, Hu Jintao and other comrades have created a giant ship for China's construction and reform. Since the eighteen, we have formed Xi Jinping's new socialist ideology with Chinese characteristics and demonstrated a prosperous and powerful China to China. In this process, the light of Marxism only increases. China's development history is also the history of our people from standing up to becoming rich and then to becoming strong. In this process, Marxism has been continuously sinicized and produced a series of rich fruits of new ideas, which has always been our powerful ideological weapon [4]. We should be consistent with Marxism, because the facts of the historical replacement process of modern Chinese society have fully proved that only Marxism and the implementation of Marxism can achieve sustainable progress.

In the process of implementing Marxist theory, there is another important work that can not be ignored, that is, the dissemination of Marxism. Since its founding, our party has never stopped spreading Marxism and has never forgotten to publicize the party's guiding ideology. From the party's Centennial journey, it is not difficult to see that our party is good at ideological and propaganda work. Whether it is with the peasants, the workers, or even the feudal forces and the bourgeoisie, our party can suit measures to individual conditions. Whether in the revolutionary era or in today's construction era, our party always keeps in mind the ideological education work, transforms its mind and deeply influences it. The publicity of Marxism is carried out in the form of a series of debates, debates or newspapers, newspapers and periodicals, and then today's Internet technology or school ideological and political education. It is aimed at people from all walks of life, men, women, old and young, and realizes the improvement of people's thought 
and quality. Marxism is feasible in China because the Communist Party of China has always implemented and publicized Marxism in its hundred years of struggle, integrated it with China's soil, and let China move towards a bright and beautiful future.

\section{THE COMMUNIST PARTY OF CHINA INNOVATED MARXISM}

The reason why Marxism "works" is that the Communist Party of China has the courage to self revolution in the new era, and Marxism still has a place to play in the contemporary world. The courage and strength of self revolution are not universal and common. If our party has this courage and ability, it will have the greatest advantage. No mistake is not equal to perfection and greatness. The real greatness lies in not hiding from doctors. It is worth pondering how to maintain the revolutionary spirit, how to always maintain its own advanced purity, and how to manage a "huge" country like China well. The weight of the word "revolution" is that "new" replaces "old" and rebirth one's "life", which is reborn. The self Revolution represents the "ruthless hand" to oneself. Only courage is not enough, but also the ability of self revolution and perseverance. The reason why our party can do this is because our party is born for the country, the nation and the people. It always represents the interests of the "public" and has no selfish desires. Since there is no nature of seeking profits and serving oneself, self revolution is natural. The development of self Revolution requires the ability of planning. This ability includes insight into the times, grasp of reality, absorption of history and confidence in striving to build a communist society. Throughout the history of the party, it is not difficult to find that many party leaders are good at adjusting the pace of the party in time according to different conditions, and have the spirit and ability of self revolution. In addition, self revolution needs to be consistent. It does not mean that there will be no revolution after the revolution, nor does it mean that there will be no revolution now after the revolution in the past. Self revolution is a dynamic and long-term historical process, and giving up halfway is not the quality that a qualified Marxist should have. Over the past hundred years, no matter how the environment changes, our party has always adhered to its own purpose, adjusted the specific pace according to the times, actively made self revolution, and followed it all the way to the end. General secretary Xi Jinping has always said that our goal of striving for success should be people's yearning for a better life. This concern for the people also fits perfectly with the people nature of Marxism. The people are the masters of the country. Only when Marxism speaks for the people can the people accept Marxism [5]. In the new era, the people have higher pursuit and demand, so we should try our best to meet this demand, which is also the requirement of Marxist theory itself for the party. In the new era, the party has the courage to self revolution and meet the requirements of Marxism, which is not only the recognition of the party's ruling ability, but also the result of the role of the party's guiding ideology. This is also the image answer and proof of why Marxism "works".

General secretary Xi Jinping put forward the new expectation to the party in the party must be brave in self revolution. He pointed out that "Change their mistakes into good, and understand their mistakes into brightness", and constantly emerging problems need people to constantly solve, and it is the emergence of problems that we are in progress and development. Anything that stagnates will not cause problems. Therefore, we should not be afraid of the emergence of problems, let alone avoid problems. Facing problems seriously and actively looking for ways to solve problems are the best way to suit the remedy to the case. Only in this way can we always keep up with the requirements of the times, practice and the people. It is the self revolutionary spirit of the Communist Party of China, which is not afraid of problems and correct mistakes, that makes Marxism still glow with strong vitality in the contemporary world. It still stands the test of practice and can guide practice. The Communist Party of China is the life bred by the combination of Marxism and China's workers' movement. It is rooted in practice. It is not an empty and pure theoretical party. Marxism is not a pure theoretical theory. It is precisely because it is a practical theory that makes its combination with the workers' movement possible. The self revolution of the Communist Party of China includes the innovation of Marxism, and on the basis of self revolution, the party has further innovated Marxism at the superstructure level. The theory derived from practice has practical function and time value, and Marxism is not outdated. Over the past hundred years since the birth of Marxism, countless people with ulterior motives have tried to prove that Marxism is no longer applicable to contemporary society, but they do not know that this proof itself is the best proof that Marxism is not outdated. Some bourgeois scholars claim that Marxism has gone bankrupt while persistently criticizing Marxism. This self contradictory trick is ironic. In Marxism: for and against, American scholar Hale Bronner clearly pointed out that the development of human society still conforms to the laws predicted by Marx a hundred years ago. Socialism is a historical necessity. From the perspective of the world, the disadvantages of capitalism are constantly emerging, and the scientific points of socialism and Marxism are irrefutable. [6]. In terms of contemporary Chinese society, socialist China is on the road to becoming a powerful country under the leadership of the party. We neither follow the old road of history nor copy the way out of other countries, nor stay in the theoretical 
imagination of typical Marxists. We regard these as "reference books" rather than "textbooks". Based on the land of China, the Communist Party of China has made Marxism a flower of characteristics and concrete tangible flowers. It is the Communist Party of China that has played a role as a bridge and link. Marxism does not just stay at the level of intellectuals and so-called elites, but more importantly, it penetrates and penetrates into the public. As Mao Zedong once brilliantly pointed out, we say that Marxism is right, it is not certified by recognized authorities, nor is it proved by another theory, but in our practical actions. Today, when we talk about the "works" of Marxism, it changes with the changes of practice, the times and the people, so it can constantly adapt to the new environment and conditions, and its accuracy has been proved by the actual situation. It is worth mentioning that Marxism is not only "works" in China. Without China, Marxism still has a place to play in the world. Marxism itself includes changing according to the situation. No matter what country or even when there is no country, Marxism has its reasonable significance. Of course, In this process, the human role of Marxism is indispensable. Socialist thought and practice have gone through more than 500 years, and have experienced the development process of gradual science, reality and national characteristics. The Communist Party of China has the courage to self revolution. Marxism, as its guiding ideology, is also self revolutionary, but it is more appropriate to say that the relationship between the two is mutual assistance than causality. The internal fit makes the Communist Party of China and Marxism go together and jointly face the self revolution of the times. Marxist theory constantly produces new theories and ideas in the new social practice, which explains the innovative charm of "the evergreen tree of theory" of scientific socialism. The "works" of Marxism lies in the innovative development of Marxism by the Communist Party of China, so that it can become a source of theory.

\section{CONCLUSIONS}

Engels once said that our theory is not mechanical dogma and unfeeling copying and recitation. The Chinese Communists treat Marxism not as a rigid dogma, but as a transfer of the historical conditions at that time, and constantly enrich Marxism with a new practice. The Communist Party of China's choice, persistence and creative achievements of Marxism fully prove and answer why Marxism "works" [7]. Today, socialist China has created "Chinese miracles" one after another. China has won an all-round victory in the fight against poverty and people's life is booming. There must be innovative practices and new ideas in this era. Under the banner of Marxism, the sparks of thought continues to flash, and everyone is approaching the direction of free and all-round development. From infancy to strength, from more than 50 people to more than 90 million people, the party has led the Chinese people through the first century of wind, rain and glory. All Chinese people are working together to courageously to achieve the two Centennial goals. This hundred years of growth process, or pain or joy, is worthy of our careful taste. Looking back at the footprints of the past step by step and thinking about today's light, the "centenarian" of the Communist Party of China is not old, but continues to glow with vitality in the new era. Our party and Marxism have experienced the same hardships. This is no longer a twilight, but a greater foundation and brilliance. Under the leadership of the party and under the guidance of Marxism, we will go through the next century, the next century, countless centuries waiting for us to set up. Every Chinese in all walks of life will make great strides forward with Chinese characteristics with the same frequency and resonance, and the Chinese nation will live forever.

\section{REFERENCES}

[1] Jianjun Liu. Why does Marxism work [J]. Guide to ideological and theoretical education, 2019(10):9-13. (In Chinese)

[2] Xianfeng Niu. Why does Marxism work [J]. China discipline inspection and supervision, 2019(15):40-43. (In Chinese)

[3] Shiluan Zhao. Understanding "four whys" from learning "four histories" [J]. Knowledge, 2020(12):33-35. (In Chinese)

[4] Xiaofeng Yan. Why does Marxism work [J]. Communist Party member (Hebei), 2019(13):10-12. (In Chinese)

[5] Weiguang Wang. Why does Marxism work [N]. China discipline inspection and supervision report, 2019-10-17(005). (In Chinese)

[6] Shuguang Chen. Why does Marxism work-History and the people have chosen Marxism [J]. Theory guide, 2019(06):25-27. (In Chinese)

[7] Publicity Department of Chongqing Municipal Committee of the Communist Party of China. Why does Marxism work [M]. Chongqing: Chongqing Publishing House, 2020. (In Chinese) 